\title{
GENERASI ALPHA : TINGGAL DIANTARA
}

\author{
Raymond Arnold Manuel ${ }^{1)}$, Agustinus Sutanto ${ }^{2)}$
}

1)Program Studi S1 Arsitektur, Fakultas Teknik, Universitas Tarumanagara, raymondarnoldmanuel@gmail.com

2)Program Studi S1 Arsitektur, Fakultas Teknik, Universitas Tarumanagara, berpikirteoripraksis@gmail.com

\begin{abstract}
Abstrak
Generasi Alpha saat ini merupakan generasi termuda lahir di tahun 2011 dengan pendekatan teknologi yang sudah semakin maju, kebiasaanya yang lekat dengan dunia teknologi sudah tidak bisa dipisahkan, namun klasifikasi generasi Alpha tidak terwujud karena tidak adanya pemerataan pendidikan, fasilitas, serta sistem yang tertinggal. Masyarakat kampung kota mengalami kesenjangan sehingga sebagian harus beradaptasi dengan kemampuannya. Penelitian ini menggunakan metode experiment material menggunakan paku dan magnet sehingga membuat spatial ruang yang unik. Reaksi yang dihasilkan menjadi metafor pergerakan masyarakat Kampung Kota di Jakarta yang saling berinteraksi sebagai nilai tukar informasi serta kedekatan yang terjadi. Hal ini sebagai konsep dasar experiment yang berhasil membuat ruang organik untuk masyarakat kampung kota khususnya generasi Alpha yang telah beradaptasi dengan perkembangan jaman. Pengalaman yang penulis bagikan merupakan sebuah pemikiran perencanaan dimasa mendatang sebagai jawaban dari "Masa depan berhuni berbasis hari ini". Tipologi bangunan yang dirancang dan penggunaan material terhadap perancangan menjadi bahan pembelajaran terhadap Arsitektur Berhuni dimasa depan. Dimana kemajuan teknologi menimbulkan masalah baru tentang disorder (kekacauan) dibalik kota modern.
\end{abstract}

\section{Kata kunci: Alpha; Experimen; Kampung Kota}

\begin{abstract}
The current Alpha generation is the youngest generation born in 2011 with an increasingly advanced technological approach, its familiarity with the world of technology is inseparable, but the Alpha generation classification does not materialize because there is no equitable distribution of education, facilities, and systems that are left behind. The urban village community experiences gaps so that some have to adapt to their abilities. This study uses an experimental material method using nails and magnets to create a unique spatial space. The resulting reaction becomes a metaphor for the movement of the Kampung Kota community in Jakarta which interacts with each other as a value for information exchange and the closeness that occurs. This is the basic concept of the experiment that has succeeded in making organic spaces for urban villagers, especially the Alpha generation who have adapted to the times. The experience that the author shares is a thought of planning for the future as an answer to "The future of living based on today". Typology of buildings designed and using material for design becomes learning material for future Living Architecture. Where technological advances create new problems about the disorder behind the modern city.
\end{abstract}

\section{Keywords: Alpha; Experiment; Urban Village}

\section{PENDAHULUAN} Latar Belakang

Kejadian pandemi merupakan wabah yang menakutkan bagi seluruh umat manusia. Virus corona baru muncul dan dikenal sebagai COVID-19 memicu wabah di Cina pada Desember 2019, dan merebak di berbagai negara sehingga WHO mendeklarasikannya sebagai pandemi global (Mardatila, 2020). Guncangan ini membuat seluruh negara terancam akan virus ini, Indonesia 
telah positif terkena serangan pandemic ini. Indonesia pertama kali mengkonfirmasi kasus COVID-19 pada Senin 2 Maret 2019. Saat itu, Presiden Joko Widodo (Jokowi) mengumumkan ada dua orang Indonesia positif terjangkit virus Corona (Detik.com, 2020).

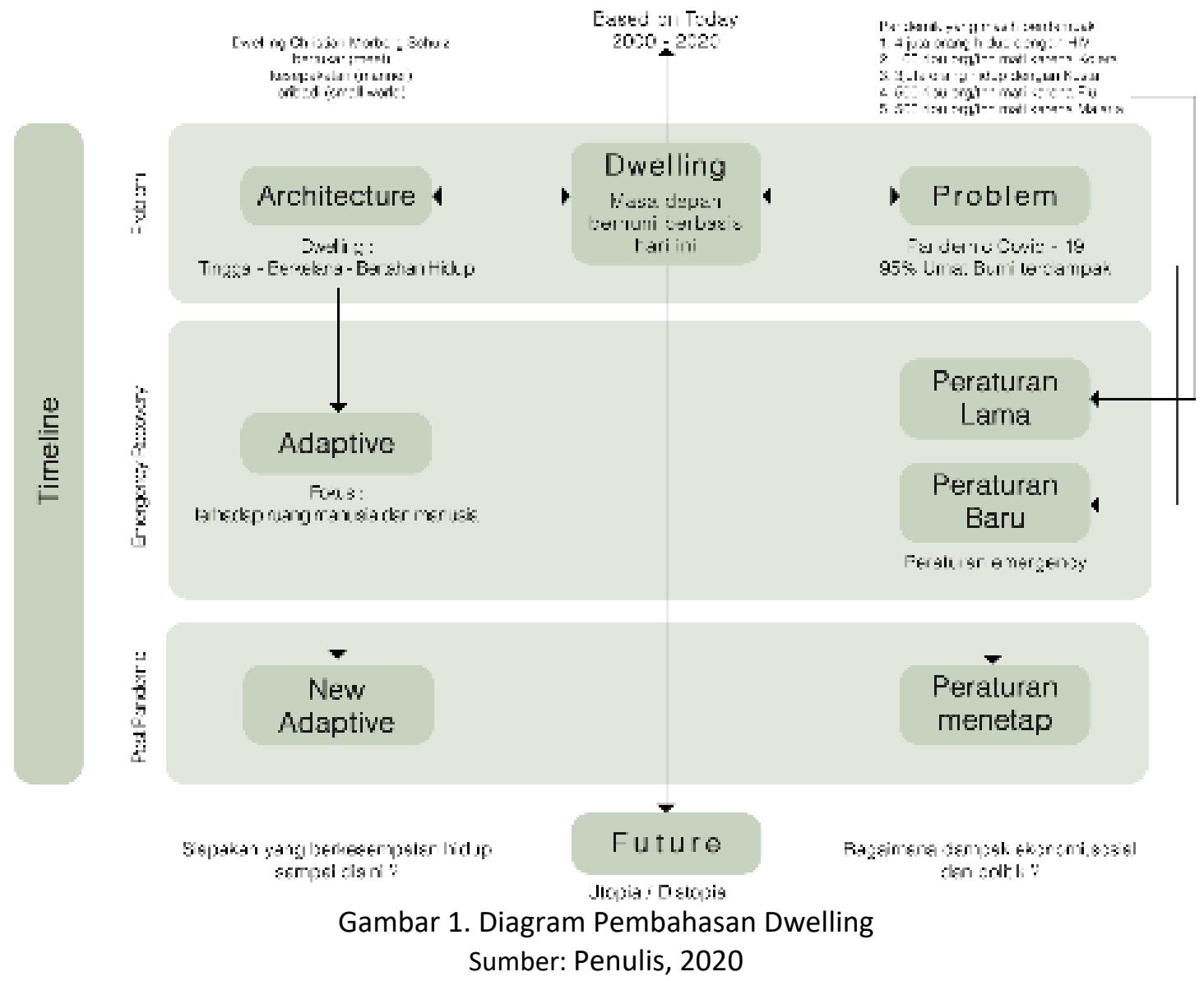

Habitat manusia berubah ketika terjadinya bencana pandemic ini. Berbagai usaha pemerintah dalam mencegah percepatan penularan virus ini. Dengan segala upaya dari pemerintah, tim medis, hingga masyarakat ikut berpartisipasi melawan pandemic ini. Di Indonesia menggunakan sistem yang dinamakan PSBB (Pembatasan Sosial Berskala Besar) Aturan PSBB tercatat dalam Peraturan Menteri Kesehatan Nomor 9 Tahun 2020. (Putsanra, 2020). Akhir-akhir ini terdapat seorang siswa SMA menyampaikan aspirasinya tentang sekolah daring (dalam jaringan) (tvOneNews, 2020). Siswa tersebut menjelaskan tentang ketidak efektifannya mereka belajar, yang mau dicapai bukan hanya ilmu tetapi mengarah terhadap karakter. Dampak ini muncul ketika peraturan PSBB berlangsung hingga ke aturan sekolah. Siswa dan Siswi ini merupakan penerus generasi pemimpin selanjutnya. Namun pendidikan di Indonesia mengkawatirkan akibat dampak pandemic ini. Siswa/siswi SMA dapat beraspirasi, namun kita harus kembali melihat pengaruh besar untuk anak-anak dibawah umur, dari Taman Kanak, SD, hingga SMP. Generasi ini kita bisa sebut adalah Generasi Y, Z dan Alpha. 

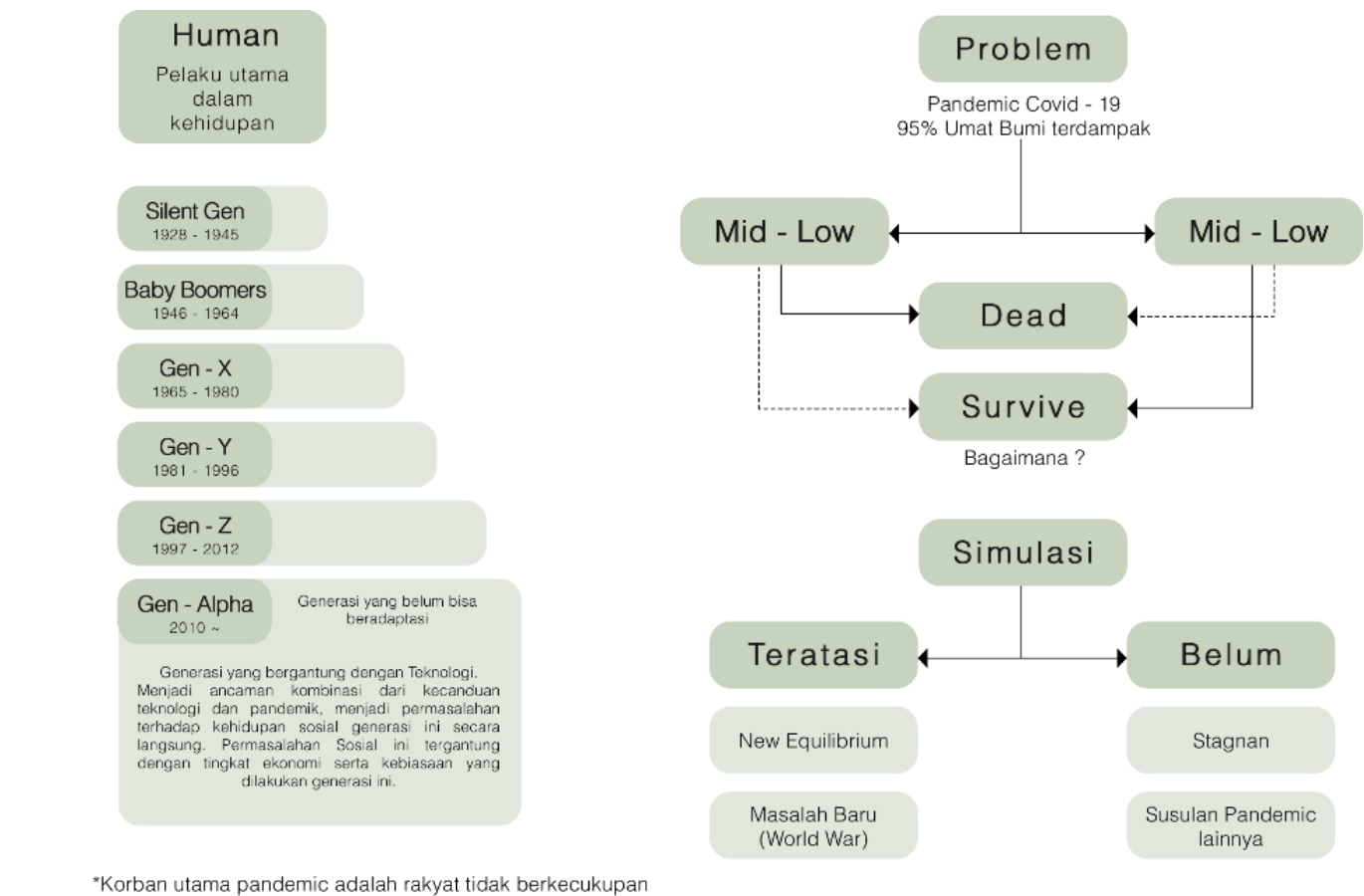

Gambar 2. Pelaku dalam pola kehidupan

Sumber: Penulis, 2020

Rencana masa depan merupakan sebuah pertimbangan yang sangat abu-abu. Namun kita harus melirik kembali apa yang harus dipersiapkan dalam kondisi pandemic. Berbagai solusi setiap saat akan selalu bermunculan, akan tetapi solusi masa depan harus dipersiapkan dengan matang dari segi teknis dan struktur pola pikir.

\section{Rumusan Masalah}

Berdasarkan latar belakang tersebut, diperoleh rumusan masalah yaitu bagaimana menciptakan sebuah tempat tinggal dimasa mendatang untuk generasi Alpha?; bagaimana desain keruangan dan bentuk arsitektur yang merepresentasikan Alpha di kampung kota?

\section{Tujuan}

Mewujudkan kehidupan generasi Alpha di kampung kota yang dapat setara dengan kehidupan generasi Alpha di kota; Menciptakan sarana yang mendukung generasi Alpha dalam beraktifitas dimasa mendatang; Memberikan kritik terhadap kelayakan kehidupan masyarakat kampung kota terhadap pemerintah; Mewadahi masyarakat dengan memenuhi kebutuhan ruang terbuka publik yang menjadi ruang dengan suasana yang berbeda dengan pendekatan experiment material sebagai konsep yang dipilih

\section{KAJIAN LITERARUR}

\section{Generasi Alpha}

Generasi Alpha adalah generasi paling muda yang hidup saat ini, yakni lahir pada tahun 2010 hingga tahun 2025 mendatang. Dimulai pada tahun 2010 yaitu bertepatan dengan era digital dimulai dimana didominasi oleh gadget. Di tahun yang sama dirilisnya generasi pertama dari IPad dan Instagram. Biasanya, generasi Alpha adalah anak-anak dari para Millenials. 


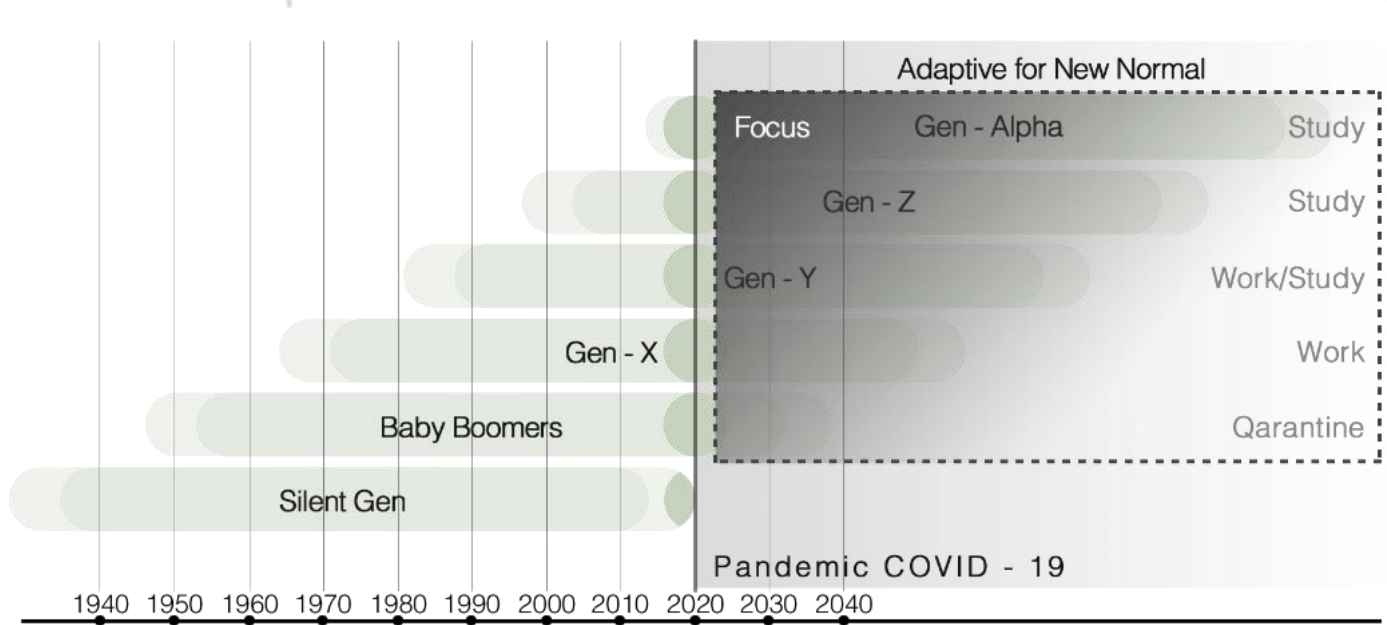

Gambar 3. Jangka waktu Perkembangan Generasi

Sumber: https://en.wikipedia.org/wiki/Generation Alpha

Generasi ini tumbuh dikelilingi oleh teknologi sebagai hiburan saat mereka berusia masih sangat dini. Kebanyakan dari orang tua mereka merupakan pengguna teknologi dan media sosial, sehingga generasi Alpha akan mengenali masa kecil mereka dengan tren yang terjadi saat ini. Anak-anak Alpha akan tumbuh dengan gadget di tangan sampai tidak pernah bisa hidup tanpa smartphone. Situasi ketergantungan teknologi pada generasi Alpha membuat mereka menjadi paling transformatif dibandingkan generasi lainnya.

\section{Karakter Alpha}

Peran Pandemi terhadap generasi Alpha merupakan sebuah dampak besar sedangkan generasi Alpha semakin akrab dengan teknologi, dan merubah karakter mereka menjadi lebih flexible, tertutup, dan lain-lain. Pernyataan ini adalah sebuah kesimpulan dari penelitian McCrindle (McCrindle, 2020) yang diambil dari Negara Australia sebagai pengaruh Pandemic terhadap Generasi Alpha.

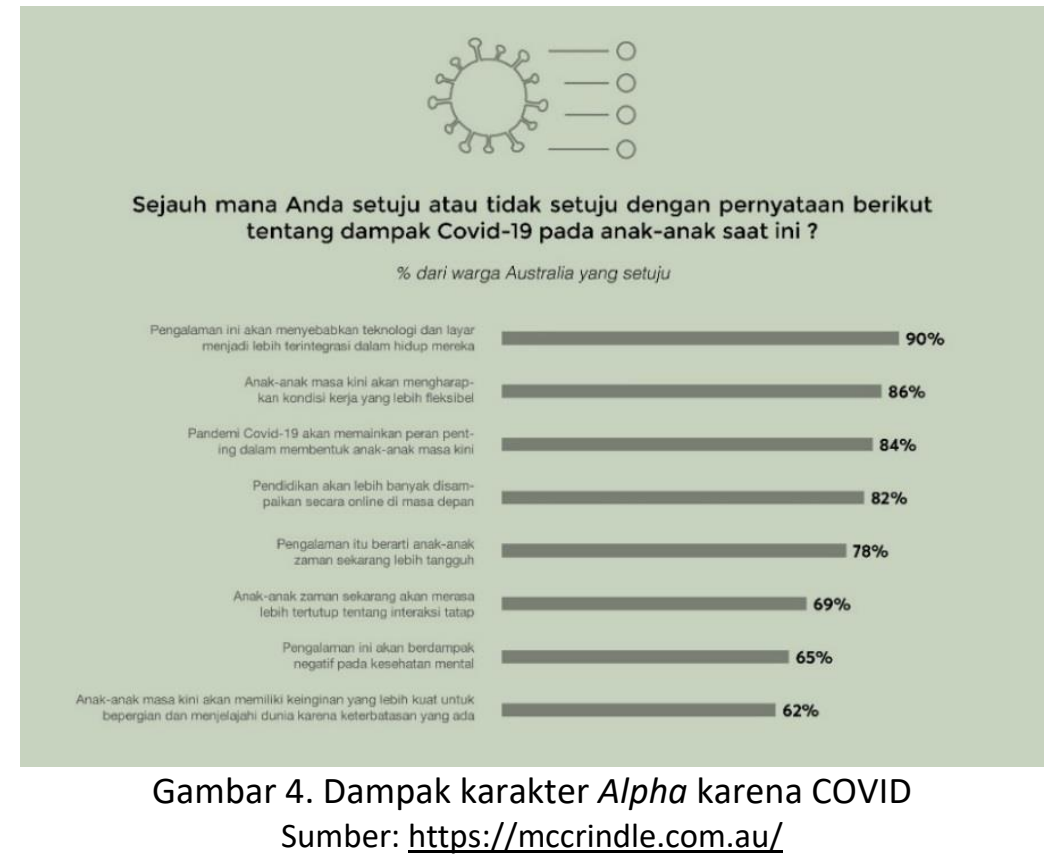

Dikarenakan adanya perubahan digital yang cukup drastis di era generasi ini, membuat mereka memiliki karakter yang mampu beradaptasi cepat dengan perubahan di lingkungan mereka. Fokus pada pembelajaran yang dilakukan untuk mereka adalah pembelajaran menambah keterampilan pada bidang tertentu, sehingga membuat bermunculannya pekerjaan baru. Anak 
pada generasi ini cenderung memiliki sifat kerja yang kolaboratif. Selain itu penggunaan sosial media sangat tinggi membuat bermunculannya influencer pada generasi ini sebagai strategi pemasaran. Berhubungan dengan itu, consumer trends pada generasi ini berorientasikan pada diri mereka sendiri. Di kehidupan sehari-hari pada generasi ini, pengakuan dari sosial merupakan yang terpenting untuk dijadikan sebuah masukan atau nasihat.

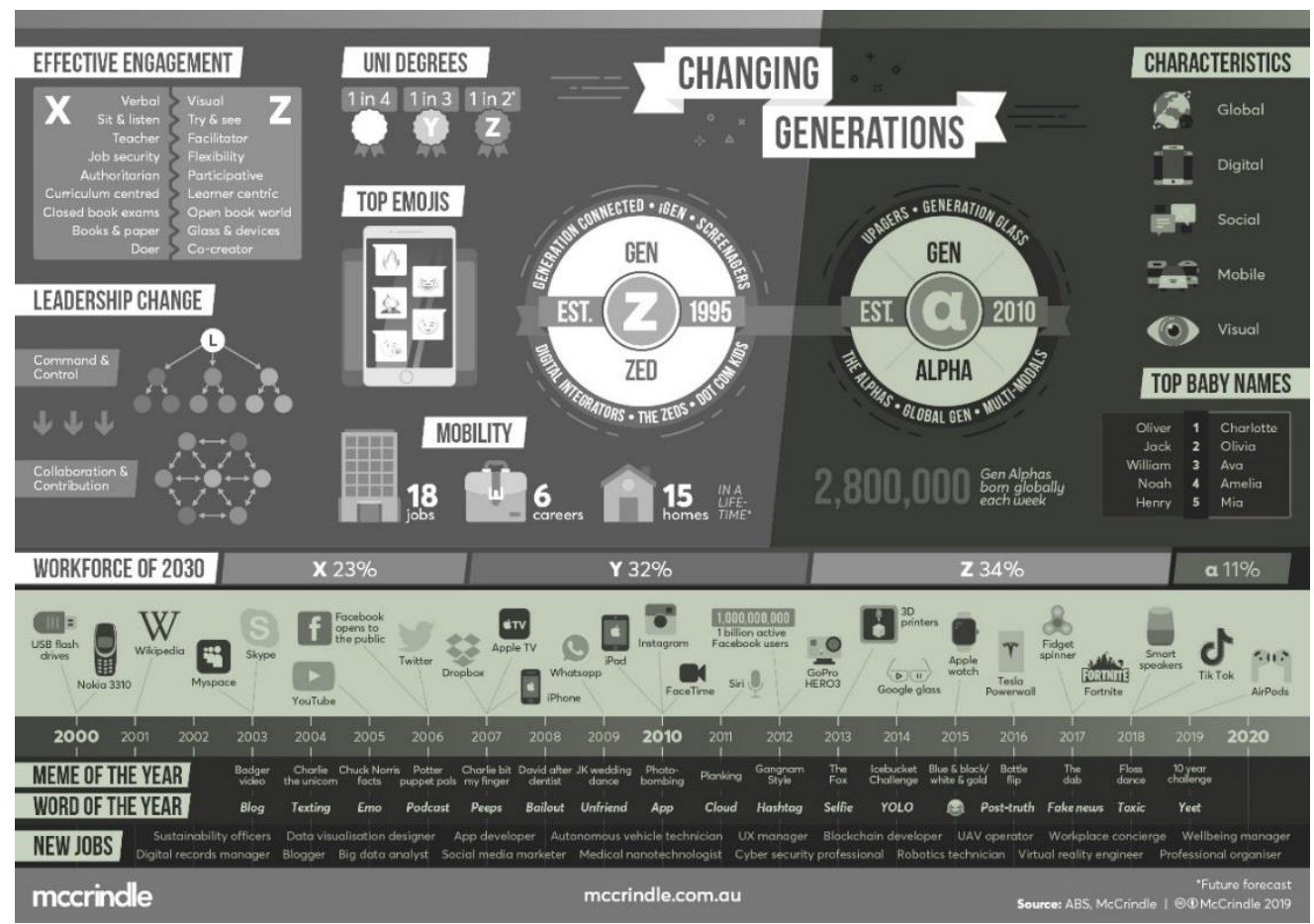

Gambar 5. Perubahan Generasi Z-Alpha

Sumber: $\underline{\text { https://mccrindle.com.au/ }}$

\section{Kampung Kota}

Kampung kota merupakan area bermukim yang tumbuh secara organik, padat penduduk, dan berlokasi di perimeter maupun tengah kota. Biasanya penduduk di kampung kota merupakan para masyarakat yang berpenghasilan rendah ataupun kaum pendatang yang bekerja di kota. Kampung berkembang melalui interaksi dan aktivitas instens yang dilakukan oleh masyarakatnya. Kampung kota memiliki perannya sendiri, sebagai penyedia opsi tempat tinggal yang lebih murah dan transisi yang manusiawi dan nyaman dari desa ke kota bagi pendatang untuk membantu perputaran roda perekonomian kota. Kenyamanan bertempat tinggal di dalam kampung terbentuk dari system berkehidupan yang identik dengan fleksibelitas dan ketahanan. Ditambah lagi kampung kota memediasi kegiatan bersama yang melampaui relasi sosial kapitalis, dimana ini dapat menjadi oase pada kehidupan kota dengan ketimpangan ekonomi yang tinggi.

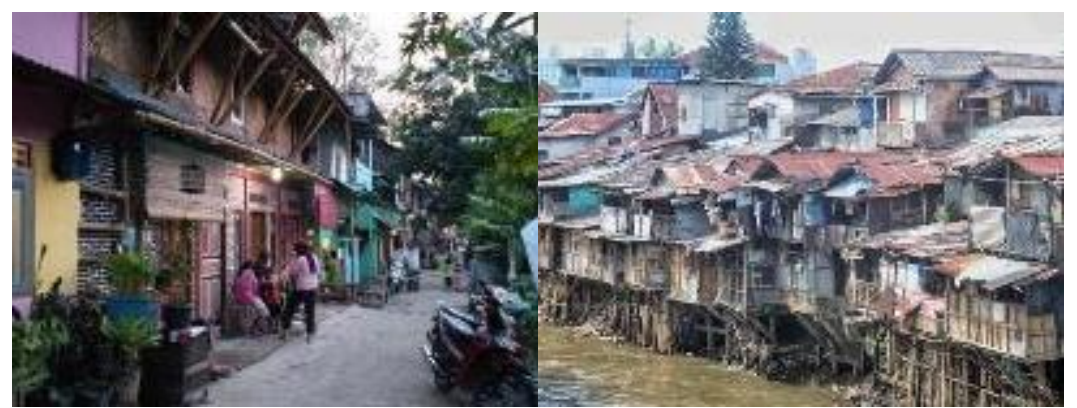

Gambar 6. Kampung Kota Tertata dan Kampung Kota Kumuh

Sumber: https://rujak.org/forum-kampung-kota-mengingatkan-anies-sandi-akan-janjinya/ 


\section{Alpha di Kampung Kota}

Alpha di kampung kota menjadi sebuah keunikan yang ada. Sebuah penelitian bahwa Alpha merupakan anak yang lahir ditahun 2011 - 2025, mereka adalah yang akrab dengan teknologi yang sudah ada. Beberapa telah dijelaskan dengan ciri-cirinya seperti perkebangan teknologi yang ada. Namun Alpha di kampung kota merupakan sebuah bentuk mutasi yang unik sehingga muncul Alpha yang berbeda dengan Alpha yang dijelaskan sebelumnya.

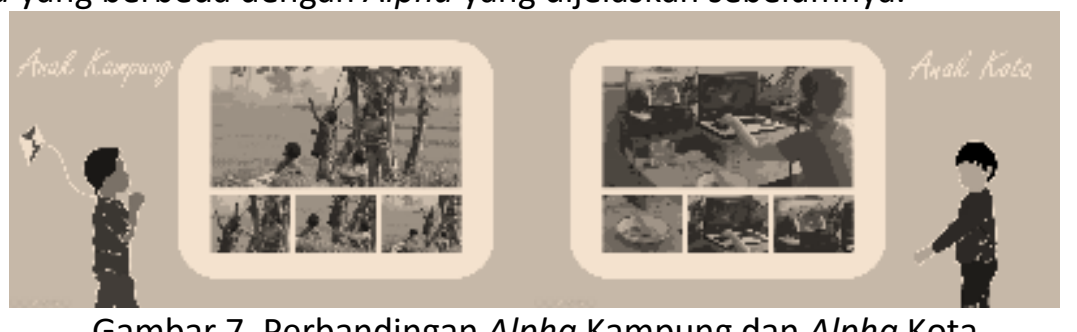

Gambar 7. Perbandingan Alpha Kampung dan Alpha Kota

Sumber: Penulis, 2020

Sebuah llustrasi menggambarkan sebuah kehidupan anak di kampung dan anak di kota. Gambar ini bukanlah kesimpulan dari kedua pembanding Alpha di Indonesia namun dapat memberi gambaran kepada pembaca dalam perspektif yang menjelaskan Alpha yang sesungguhnya di Indonesia. Pada penjelasan anak kampung terdapat sebuah penjelasan bahwa interaksi secara langsung merupakan sebuah ikatan yang nyata bagi mereka. Permainan tradisional seperti layang-layang, bersepeda, petak umpat merupakan keseharian mereka untuk menjalankan aktivitasnya. Begitu juga sebaliknya untuk anak kota. Interaksi secara tidak langsung merupakan kebiasaannya menemukan teman dalam jaringan internet. Terdapat kebiasaan yang digabungkan secara bersamaan bisa disebut multitasking. Sebuah kebiasaan yang dapat dianggap buruk atau tidak membawa hasil yaitu percepatan dalam kegiatan hidupnya, seperti bermain bersamaan menonton dan makan. Hal itu menjadi kebiasaan yang muncul karena pertumbuhan Teknologi.

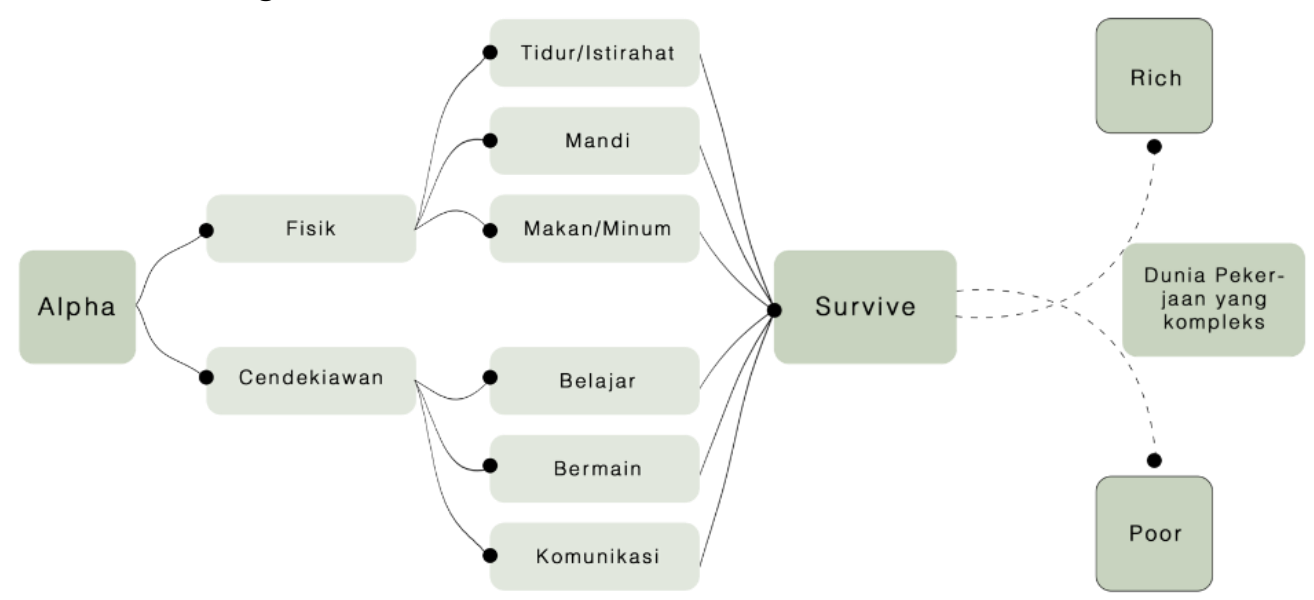

Gambar 8. Diagram Kegiatan Alpha

Sumber: Penulis, 2020

\section{METODE}

\section{Experiment Material}

Eksperimental adalah bidang antara teori dan praktis dan percobaan dan spekulasi merupakan kata kunci dari Eksperimental. Bagi Lebbeus Woods, adalah penting menetapkan eksperimental sebagai kegiatan dalam berarsitektur, karena sifat perubahan lapangan di dunia yang kontemporer ini. Arsitektur Eksperimenral bergerak dalam wilaya kreatifitas, utopis dan kebaharuan konsep, dan ini 'bertentangan' dengan praktik konvensional (Sutanto, 2020). Dasar eksperimen ini merupakan sebuah implementasi benda yang di artikan kepada sebuah 
kehidupan yang menjadi target proyek. Eksperimental ini terdiri dari paku dan magnet membuat ruang yang dihasilkan berdasarkan jarak, waktu dan gaya magnet. Paku berperan sebagai warga kampung kota yang di adaptasi dikarenakan pola perilakunya berbagi informasi secara cepat dalam lingkungannya. Pola tersebut menginsipirasi sifat magnet yang memberi gaya dengan cepat kesetiap paku yang ada. Berdasarkan penelitian pembentukan ruang terdapat kualitas ruang yang diciptakan sehingga dapat dikatakan sebuah ruang yang dapat diberikan fungsi. Dalam eksperimen tersebut terpilih 5 form yang diimplementasikan ke 5 fungsi utama, yaitu Living (tempat tinggal), Public Area (ruang publik), Office Area (kantor), Communal Space (ruang komunal), dan Workshop Area (ruang Workshop).

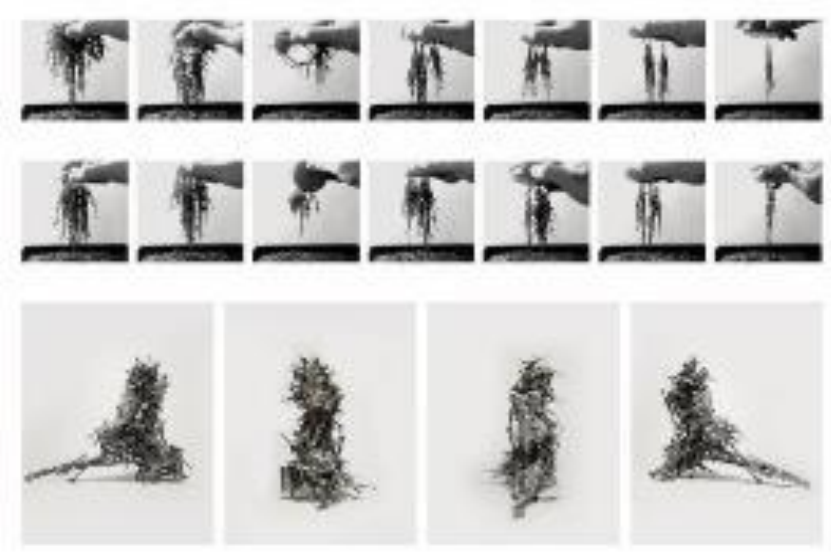

Gambar 9. Experiment Magnet dan Paku

Sumber: Penulis, 2020

\section{Experimen}

Tahap ini adalah tahap pemikiran yang secara organik terbentuk dari sentuhan designer. Dengan bermacam percobaan terjadi puluhan hingga ratusan form yang terbentuk. Bentuk yang dihasilkan selalu berbeda sesuai dengan jarak, waktu, dan gaya tarik magnet. Form ini bisa disebut seperti Rhizome (Akar).
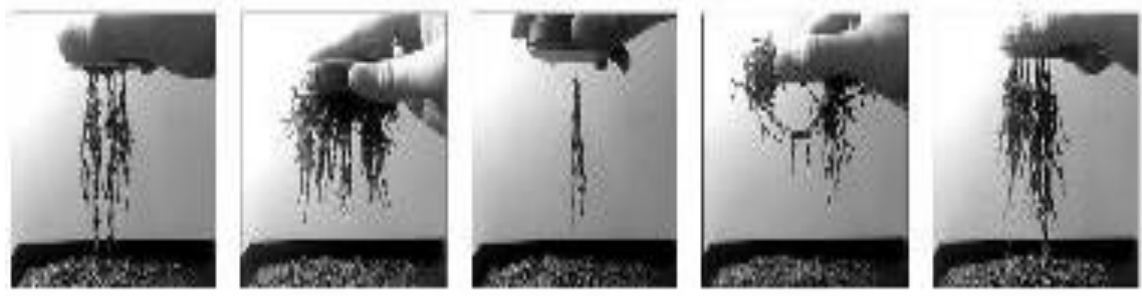

Gambar 10. Experiment

Sumber: Penulis, 2020

\section{Modeling}

Setelah melakukan experiment, memasukan experiment kedalam aplikasi sebagai model yang utuh dan sentuhan designer sebagai bentuk tetap dan struktur sementara.
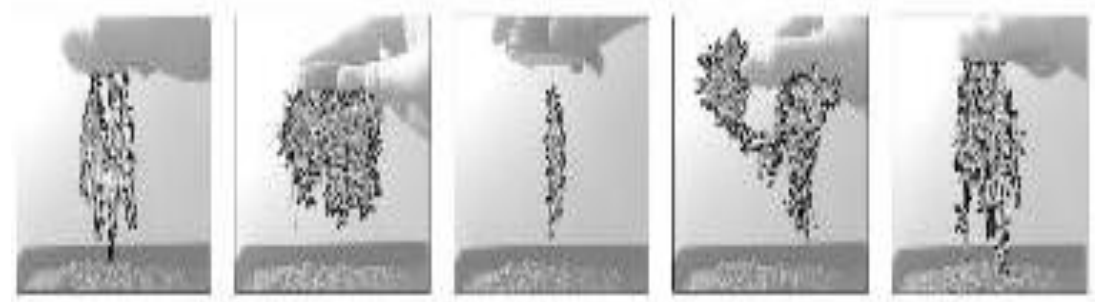

Gambar 11. Modeling

Sumber: Penulis, 2020 


\section{Section}

Untuk mengetahui kualitas ruang, maka modeling tersebut dipotong sehingga kualitas ruang terlihat dan terbentuk secara organik.
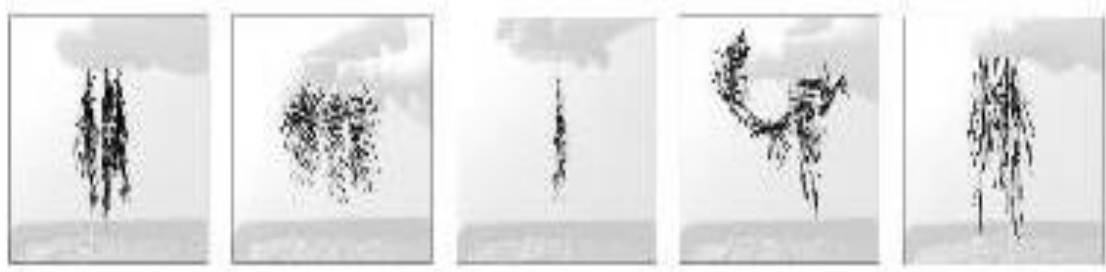

Gambar 12. Section

Sumber: Penulis, 2020

\section{Dwelling}

Untuk mencapai ruang yang sesuai dengan pola perilakunya disesuaikan kebiasaan penggunanya saat ini lalu diprediksikan kegiatan masa mendatang yang akan terjadi selama 20 tahun mendatang. Pola perilaku ini dikutip dari Kompedium Kampung kota. Kegiatan - kegiatan tersebut tidak berubah melainkan berkembang seiring perkembangan jaman.
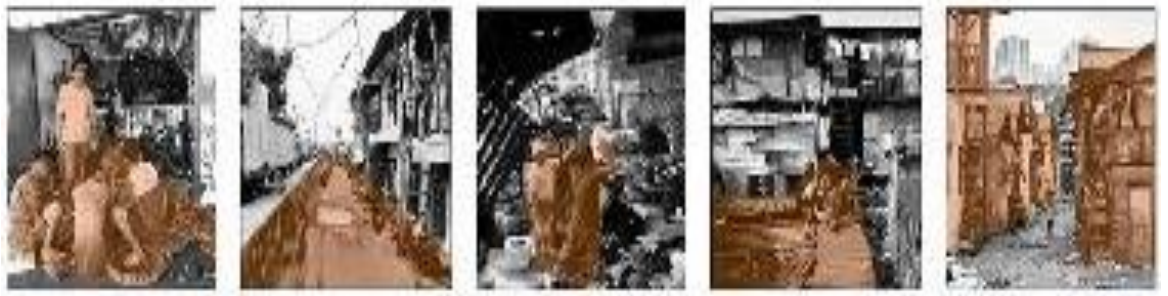

Gambar 13. Dwelling

Sumber: Penulis, 2020

\section{Environment}

Lingkungan yang tercipta adalah lingkungan baru yang diadopsi dari Dwelling yang sudah ada lalu di kembangkan menjadi suatu hal yang baru dan menyesuaikan dengan lingkungan sekitar.
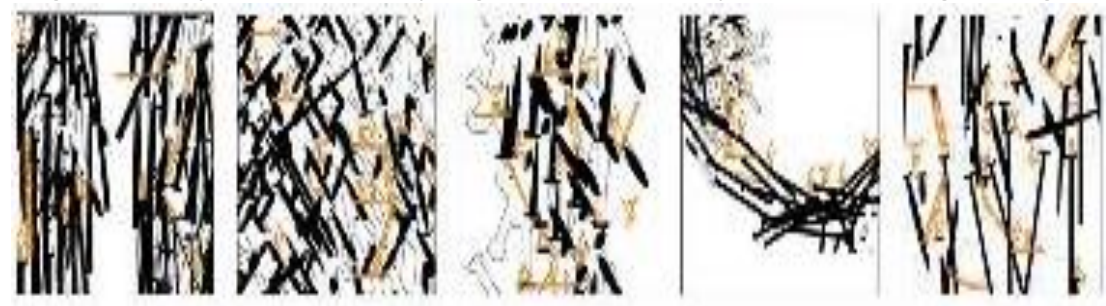

Gambar 14. Environment

Sumber: Penulis, 2020

Sketch

Sentuhan desainer untuk menegaskan design yang sudah ada menjadi suatu kesatuan form arsitektur. Bentuk yang dihasilkan menjadi ruang yang sesungguhnya.
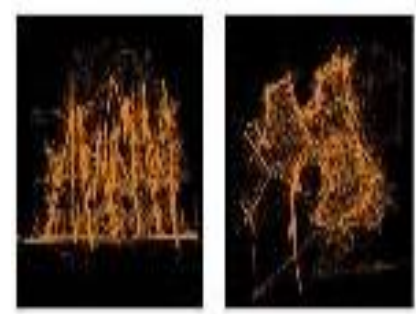
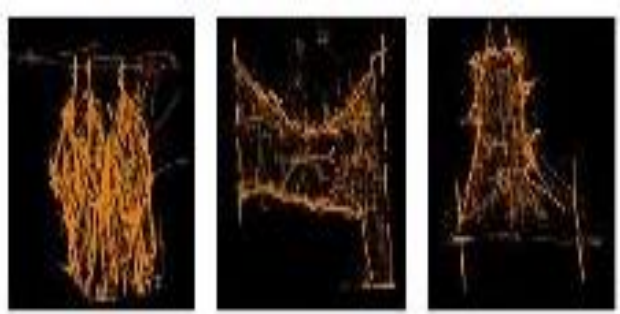

Gambar 15. Sketch

Sumber: Penulis, 2020 


\section{Structure}

Experiment Struktur juga berkaitan dengan experiment diawal, menggunakan Aplikasi 3D sketchup dengan tambahan Plug In MsPhysics menggunakan efek gerak kebawah membuat spatial ruang yang disesuaikan dengan gaya tarik magnet ke bawah (ke permukaan bumi). Struktur dibuat seperti arah jarum jam lalu diberi artikulasi sebanyak 2 - 4 artikulasi yang membuat bentuk terlihat secara organik.
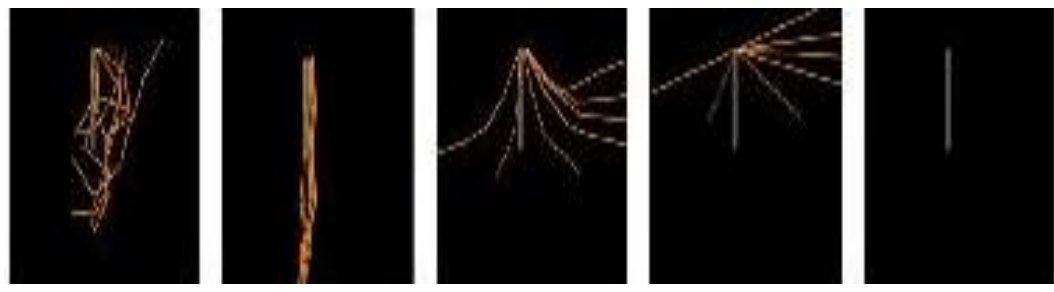

Gambar 16. Experiment Struktur

Sumber: Penulis, 2020

Result

Hasil design menjadi sebuah bentuk arsitektur yang utuh dan dapat berkembang kembali seperti sifat rhizome yang menyebar sesuai pertumbuhan penduduk secara organik.
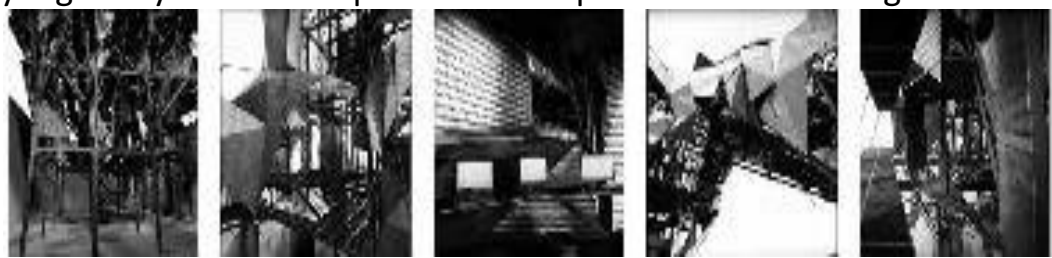

Gambar 17. Hasil experiment menjadi ruang Arsitektur Sumber: Penulis, 2020

\section{Tipologi Kampung Kota}

Tipologi Kampung kota ini menjadi dasar perencanaan proyek ini dalam menyesuaikan pola perilaku mereka dari segi kebiasaan hingga aktifitas sehingga menghasilkan sebuah program yang menyesuaikan aktifitas saat ini untuk dimasa mendatang (Gumilang, 2018). Terdapat 100 tipe tentang kampung kota dalam pembahasan kampung kota di Jakarta, seperti jemuran di gang, kicauan burung, odong-odong dan lain-lain Dalam penentuan tapak, pengamatan diperlukan dengan cara seksama, pengkategorian berdasarkan tipe dalam panduan kompedium Tipologi Kampung Kota(Gumilang, 2018) dianalisis secara visual.

\section{DISKUSI DAN HASIL} Latar Belakang Kawasan

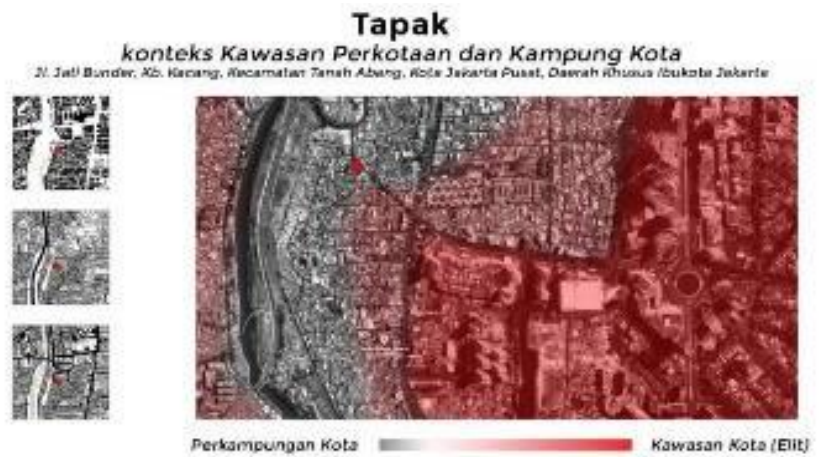

Gambar 18. Tapak berdasarkan tingkat ekonomi.

Sumber: https://www.google.com/maps/place/Tanah+Abang (data diolah) 
Tanah Abang adalah pusat grosir tekstil terbesar di Asia Tenggara. Pembeli yang datang ke Pasar Tanah Abang dari penjuru pelosok negeri hingga mancanegara semisal Malaysia. Dari mulai berdiri hingga kini, Pasar Tanah Abang telah mengalami banyak perubahan bangunan dan desain. Sejarah Pasar Tanah Abang berdiri sejak 30 Agustus 1735. Dulu, Pasar Tanah Abang bernama Pasar Sabtu. Pasar ini dibangun oleh Yustinus Vinck. Yustinus Vinck mendirikan Pasar Tanah Abang Pasar atas izin dari Gubernur Jenderal Abraham Patramini (Hermawan, 2019). Tapak ini diambil dikarenakan merupakan sebuah tapak yang terlihat sekali perbedaan status sosialnya yang terjadi. Dalam gambar 18 . Diperlihatkan gradasi kawasan elit dan tidak. Ini terjadi dikarenakan perubahan jaman dan perubahan ekonomi secara drastis. Pertambahan peminat pembelanja ke Tanah Abang semakin tinggi, sedangkan angka kemiskinan juga bertambah. Muncul PKL (pedagang kaki lima) secara illegal serta tindak kriminal semakin banyak. Sehingga tampak tanah abang semakin Semerawut (Hermawan, 2019).

\section{Data Tapak}

Tapak yang diambil terdapat dua bagian, untuk yang pertama tapak di ambil tepat di Rumah Susun Kebon Melati Jati Bunder, yang beralamat No., Jl. Jati Bunder No.42, RT.16/RW.9, Kb. Kacang, Kecamatan Tanah Abang, Kota Jakarta Pusat, Daerah Khusus Ibukota Jakarta 10240.

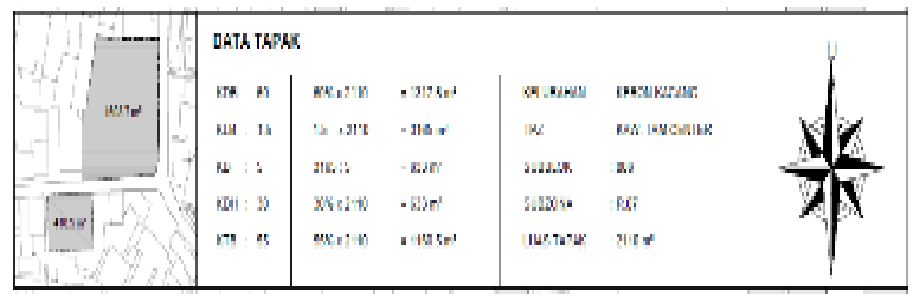

Gambar 19. Data Tapak

Sumber: Data Pribadi
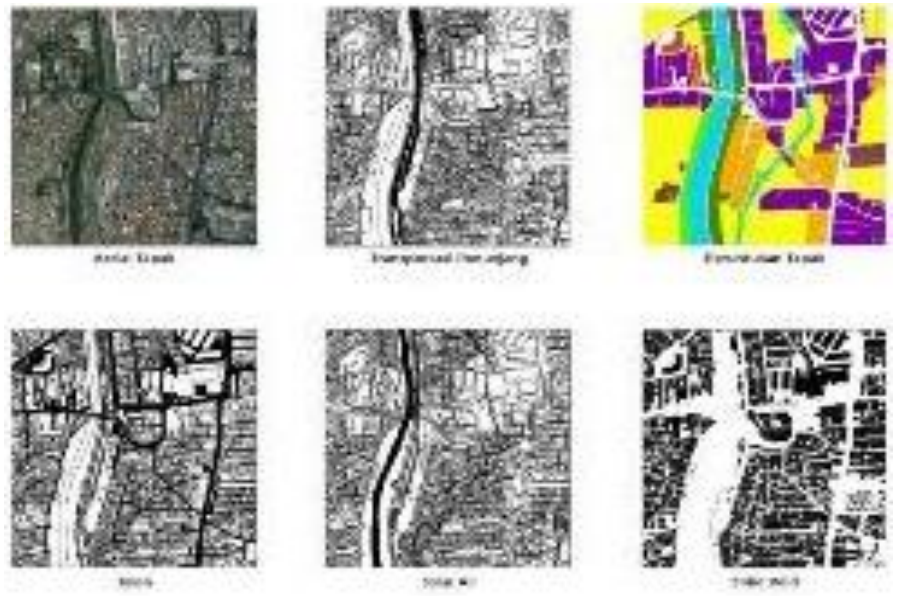

Gambar 20. Analisis Tapak

Sumber: Penulis, 2020

\section{Aerial Tapak}

Tapak berada diarea distrik pembelanjaan yaitu Tanah Abang, Tanah Abang merupakan distrik perbelanjaan tekstil terbesar. Dalam hal ini tapak berada di kawasan padat penduduk. Di Utara tapak terdapat pasar Tanah Abang, di bagian Barat tapak terdapat Rel Kereta api dari Stasiun Tanah Abang, serta Sungai Ciliwung, di bagian Selatan terdapat kantor Lurah Kebon Melati, dan di bagian Timur mengarah ke Monumen Selamat Datang, kawasan JI. M.H. Thamrin.

\section{Transportasi Penunjang}


Transportasi penunjang kawasan tersebut terdapat Stasiun Tanah abang sebagai stasiun besar kelas B. Stasiun Tanah Abang sebagai stasiun transit berbagai arah. Stasiun Tanah Abang melalui tujuan Jatinegara, Bogor, dan Rangkasbitung. Lalu transportasi lain juga terdapat Transjakarta yang melintasi Tanah Abang dalam radius 500 meter sehingga perlu berjalan/ naik kendaraan sebelum ke Halte Transjakarta yaitu Halte JI. Jembatan Tinggi.

\begin{tabular}{|c|c|c|}
\hline .po! & sut & 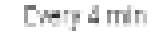 \\
\hline JPOA & mer & Fompd un \\
\hline Mot & 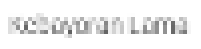 & Exy a min \\
\hline M11 1 & Herus & Ewery limin \\
\hline HOA & ÁBoran Lam & Exy' $15 \mathrm{~m} n$ \\
\hline 102 & opulat & Tuny 15 min \\
\hline
\end{tabular}

\section{Peruntukan Tapak}

Gambar 21. Jurusuan Bus Halte Jemb. Tinggi Sumber: https://www.google.com/maps/preview

Peruntukan tapak telah diatur dalam Peta Rencana Kota. Tapak berada di dua warna yaitu, K.2 dimana tempat zonasi bangunan umum, perkantoran, perdagangan dan jasa, dan R.7 zonasi Perumahan Vertikal. Fungsi ini sudah disesuaikan dengan Proyek yang dibuat.

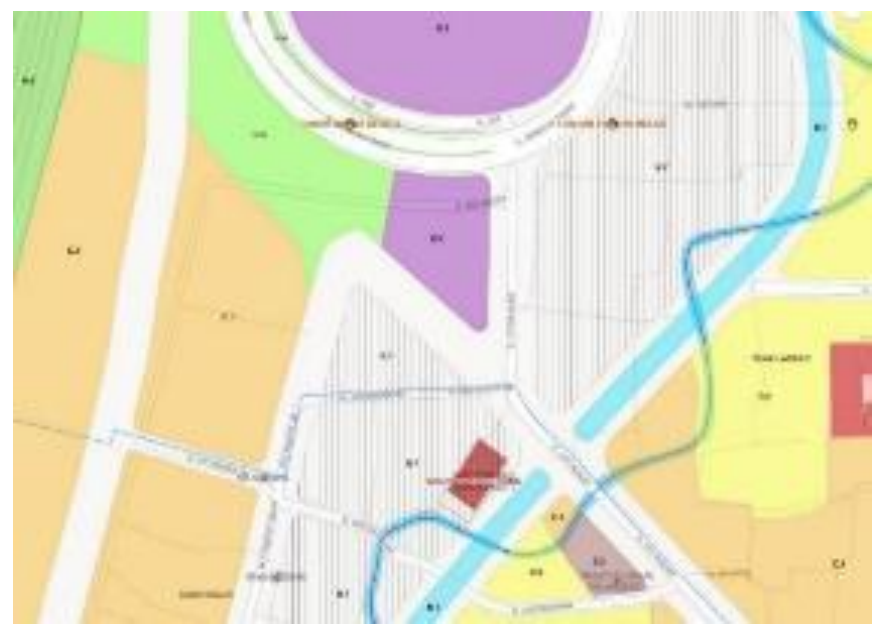

Gambar 22. Peta Zonasi Tapak

Sumber: https://jakartasatu.jakarta.go.id/

Jalan

Lokasi site berada dekat dengan Jl. Jembatan Tinggi, dan dekat dengan jalan besar yaitu Jl. Ks. Tubun dan Jl. H. Fachurdin yang melintasi Pasar Tanah Abang. Jalan ini merupakan jalan padat pengunjung dikarenakan kepadatan pasar, PKL, serta banyak kendaraan umum berhenti seperti angkutan umum dan Kopaja. Site sendiri berada di Jalan Jati Bunder, lebar jalan \pm 5 meter, hanya muat untuk 2 mobil saja. Aktivitas pada jalan ini tergolong ramai dan aktivitas ekonominya berupa jajanan makanan serta beberapa terdapat toko servis. 


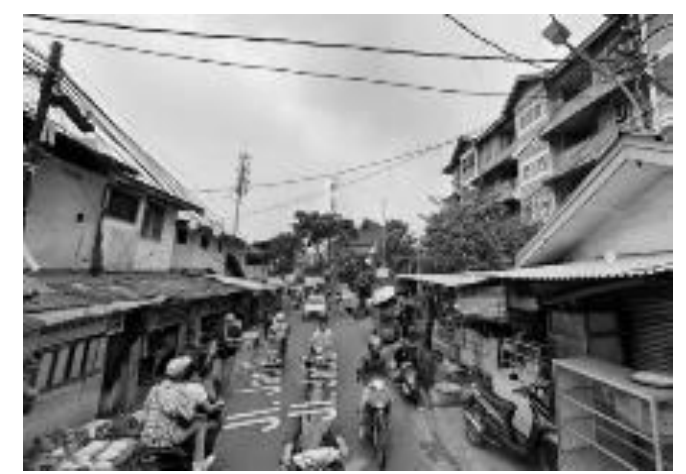

Gambar 24. Jl. Jati Bunder

Sumber: https://www.google.com/maps/preview

\section{Jalur Air}

Terdapat Sungai di sekitar tapak yaitu sungai Ciliwung yang bersebelahan dengan rel kereta Stasiun Tanah Abang. Terdapat juga sungai kecil yang berasal dari Sungai Ciliwung yang mengalir disekitar tapak dalam radius $\pm 100 \mathrm{~m}$, namun untuk kebersihan sungai tersebut tidak terkendali dikarenakan sungai tersebut sebagai wadah pembuangan warga sekitar. Sehingga kebersihan diarea ini sangatlah tidak terawat.

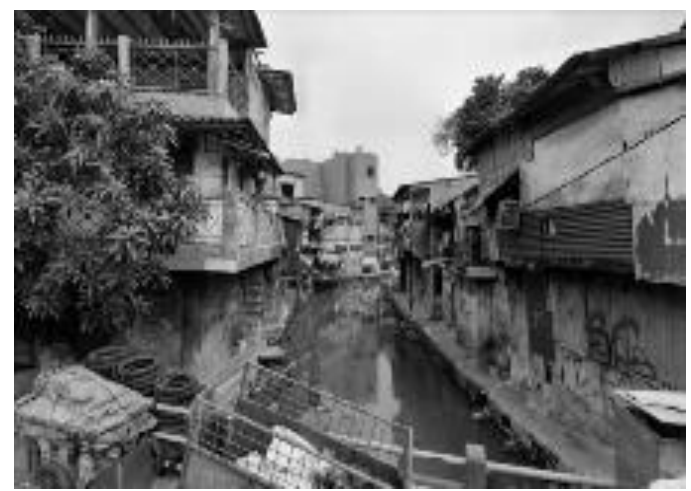

Gambar 25. Kondisi Sungai Ciliwung disekitar tapak. Sumber: https://www.google.com/maps/preview

Solid Void

Kepadatan penduduk ditentukan dari data BPS yang ada, untuk kepadatan penduduk sendiri 13.540/km2 (tingkat kecamatan Tanah Abang). (ENSIKLOPEDI, 2017)

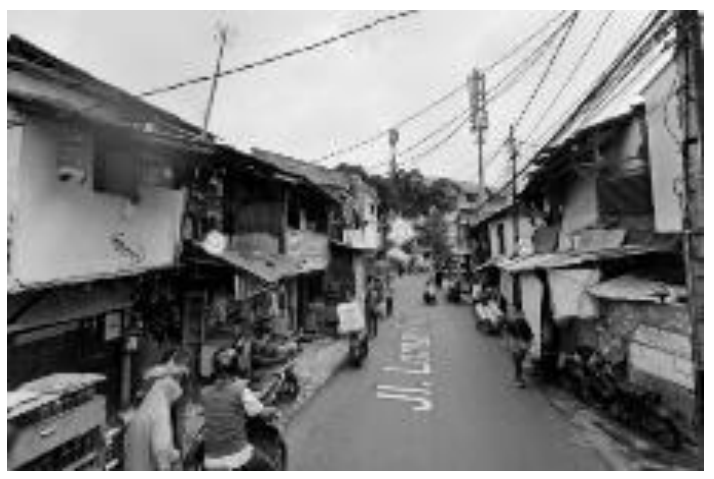

Gambar 26. Kondisi kepadatan penduduk area Jati Bunder. Sumber: $\underline{\text { https://www.google.com/maps/preview }}$

\section{Program Ruang}




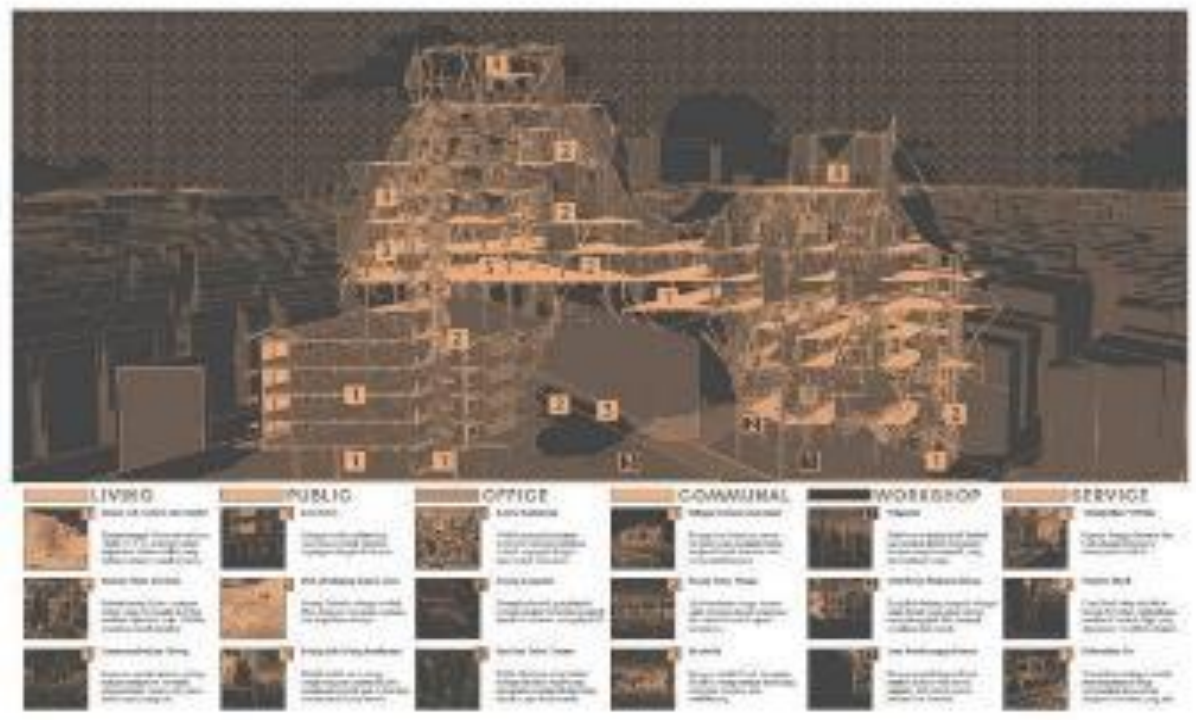

Gambar 27. Program Ruang Proyek

Sumber: Penulis, 2020

\section{Tempat Tinggal}

Tempat tinggal menjadi wadah untuk generasi Alpha, sebuah kebutuhan yang memenuhi kebutuhan perkembangan jaman sangat dibutuhkan. Dari segi Teknologi hingga keadaan sekitar sesuai dengan lingkungan sebelumnya. Rumah dibikin seperti tipe unit dan disusun secara linear, namun untuk perkembangan tiap rumah dibiarkan bertumbuh secara organic sehingga bentuk rumah yang dirancang hanyalah sebagai pemancing design pemiliknya sendiri. Konsep ini diterapkan juga seperti Half house di Chile. Pertumbuhan ini yang dimaksud seperti Rhizome menjalar secara bebas seperti akar dari sumbu $X, Y$, dan Z. Program living tidak hanya tempat tinggal yang dirancang dalam eksperimen, namun terdapat dua lagi yaitu living sebelumnya yaitu Rusun Jati Bunder sebagai bangunan induk dari proyek ini. Bangunan ini berdiri diatas banguanan lama yang tak layak huni. Namun dengan adanya bangunan ini menjadi hidup kembali dan seperti inang ditumbuhi oleh sebuah parasit yang bisa menguntungkan maupun merugikan.

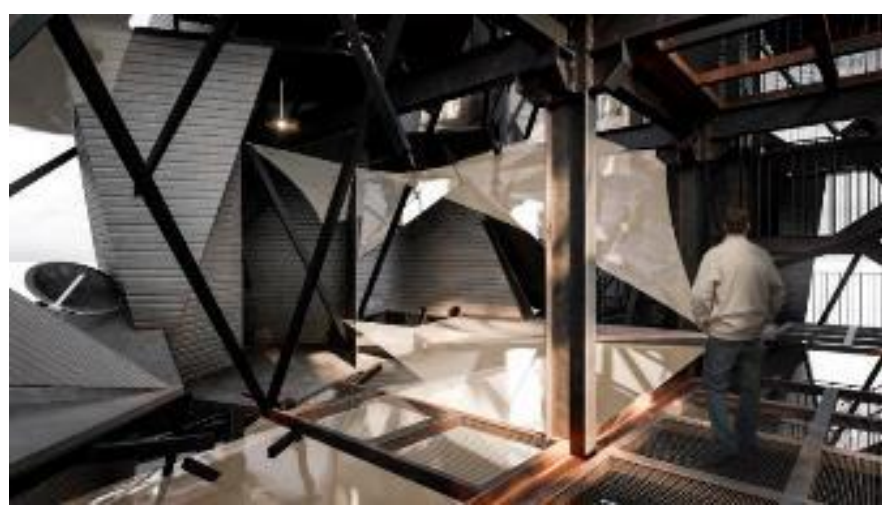

Gambar 28. Living Area

Sumber: Penulis, 2020

\section{Ruang Publik}

Ruang publik terbentuk diharapkan terbentuk secara organik diarea lantai 1, sebuah ruang yang sudah terbentuk dari sebelumnya sebagai area jajan, dapat memicu lebih ramai lagi sebagai ruang jualan, seperti pasar kebutuhan sehari-hari dan pasar jajanan. Kepadatan penduduk ini menjadi Oppurtunity untuk para pedagang mengisi bayangan dari bangunan ini. Dalam 
perencanaan ruang publik untuk memberi kesan keruangan yang terbuka telah diberikan fasilitas seperti ruang parkir, tempat sampah umum, serta lahan secara linear.

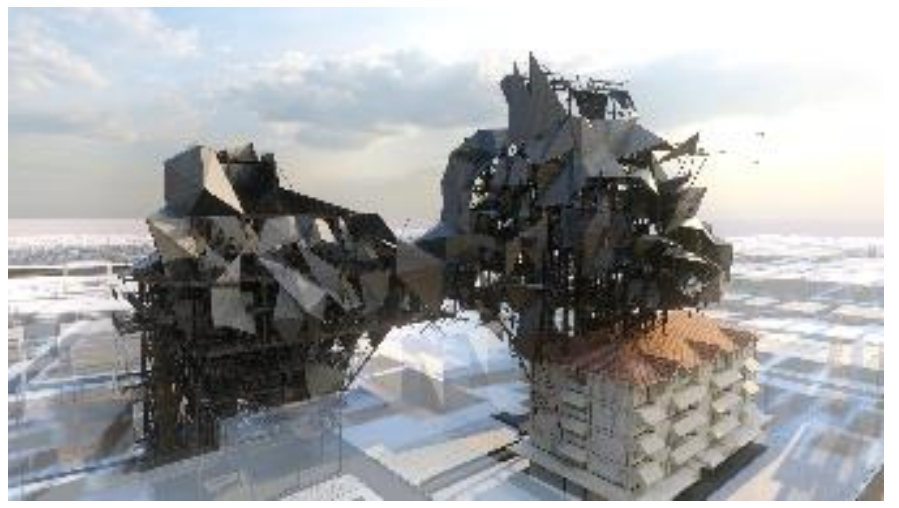

Gambar 29. Ruang Publik

Sumber: Penulis, 2020

Ruang Kerja

Kantor ini difungsikan sebagai ruang bekerja bagi generasi Alpha, bisa dikatakan ini adalah sebuah wadah startup untuk generasi $A$ lpha disana, penggunaan fasilitas ini diperuntukan untuk membantu generasi Alpha dalam bentuk fasilitas keruangan dan komputer demi menyetarakan kualitas generasi Alpha kampung kota dan generasi Alpha yang ada di kota. Sebagai fungsi office, juga memiliki fungsi lainnya seperti ruang kumpul dan toilet umum yang dipakai bersamaan.

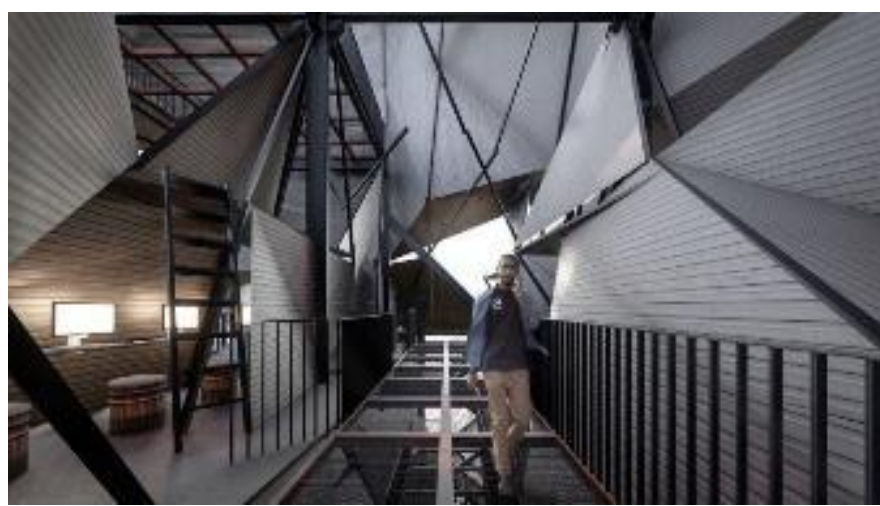

Gambar 30. Area Kantor

Sumber: Penulis, 2020

\section{Ruang Komunal}

Ruang Komunal sebagai suatu ruang yang mewadahi aktivitas utama yaitu tinggal dan bekerja. Sebuah interaksi langsung merupakan sebuah kebiasaan Warga kampung kota yang sudah dipastikan akan menurun ke generasi Alpha ini. Sehingga ruang yang dibentuk seperti jembatan saling berhubung serta diberikan fasilitas umum yang biasa mereka pakai seperti WC/KM umum dan ruang cuci bersama adalah sebuah wadah untuk kaum wanita yang ingin mencuci baju dan mencuci piring sehingga muncul interaksi. Tidak hanya itu untuk bagian Komunal Space diberikan sebuah Musholla umum untuk mewadahi individual yang tinggal dalam Proyek ini. Untuk ruang komunal space diberikan keluasan dan sebagai ruang imajinasi anak dalam bermain. Sehingga dari segala kalangan yang akan datang telah terpenuhi dari segi keruangan. 


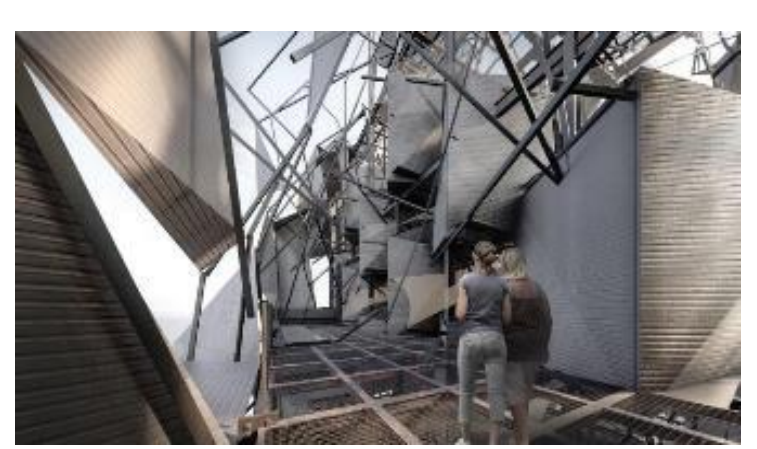

Gambar 31. Ruang Komunal

Sumber: Penulis, 2020

\section{Ruang Workshop}

Workshop merupakan sebuah program yang diberikan kepada generasi Alpha untuk mengeksplor barang bekas yang mereka kumpulkan, sehingga mereka tidak dapat berhenti menciptakan sebuah benda dimasa mendatang. Terinspirasi dari kegiatan pengepul dan bengkel rumahan yang ada di Kampung tersebut. Memungkinkan untuk menjadi sebuah kesatuan bagi mereka yang memiliki kemampuan untuk saling melengkapi dalam menciptakan sesuatu dalam wadah yang diberikan. Workshop sendiri bukanlah hanya untuk menciptakan barang, namun juga sebagai kontraktor portable yang dididik untuk membuat ruang tinggal / kator sesuai dengan eksperimen bangunan.

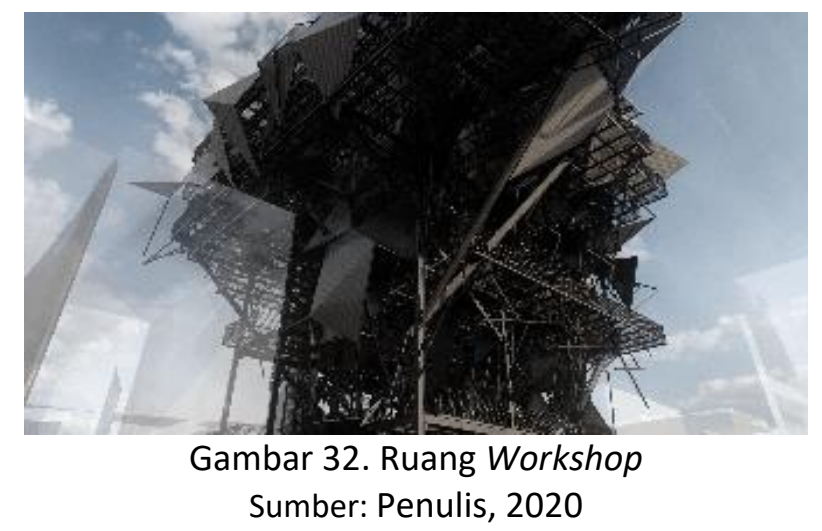

Servis

Servis adalah program wajib dalam kebangunan, sirkulasi vertikal menjadi sebuah peran penting dalam berkelangsungan hidup, dari segi servis keamanan dan kenyamanan serta kebutuhan penduduk dalam menjalankan aktivitas yang ada, servis mewadahi dari segi kenyamanan tinggal seperti fasilitas instalasi pemadam kebakaran, tangga darurat (tangga umum outdoor) serta kebutuhan air di lantai rooftop, kebutuhan air mengalir tujuannya umum untuk menyamaratakan kebutuhan masing-masing individual.

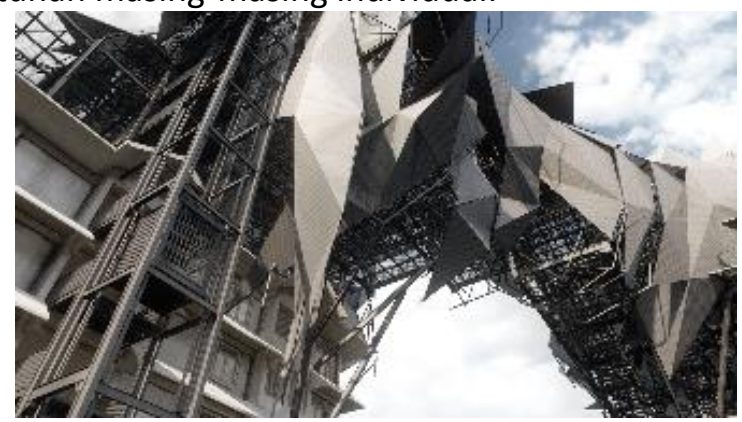

Gambar 33. Servis

Sumber: Penulis, 2020 


\section{KESIMPULAN DAN SARAN}

\section{Kesimpulan}

Dalam kehidupan saat ini Pandemic merupakan sebuah guncangan dunia terhadap perubahan yang sangat drastis. Perubahan ini sangatlah berpengaruh terhadap generasi yang akan datang. Namun untuk mengetahui lebih spesifik generasi yang paling baru adalah generasi Alpha. Alpha adalah generasi yang paling dekat dengan generasi sebelumnya yang akrab dengan teknologi. Dwelling yang ingin dibentuk berupa wadah tempat tinggal seperti hunian dan ruang public disatukan untuk menampung kegiatan dimasa depan, akan tetapi fokus berikutnya adalah Lokasi yang dipilih. Lokasi yang dipilih merupakan lokasi yang jauh dikatakan berkembang, dikarenakan lokasi yang dipilih merupakan sebuah area kampung kota yang memiliki karakter berbeda dibanding area kampung maupun area kota yang sudah maju. Kampung kota adalah sebuah wadah yang unik untuk dipelajari dikarenakan mereka mempunyai kebiasaan- kebiasaan yang berbeda dengan masyarakat kota dan kampung lainnya. Mereka berusaha bertahan hidup dalam perbedaan, pendatang baru selalu bertambah serta penyesuaian sangatlah sulit dilakukan untuk mengejar kesetaraan masyarakat yang sesungguhnya. Hal ini dikarenakan masyarakat kampung kota kebanyakan memiliki status ekonomi yang rendah, oleh karena itu proyek ini dibentuk untuk meningkatkan sebuah ekosistem yang terbarukan serta menjamin generasi Alpha kamung kota yang siap bertahan hidup di kemudian hari.

Dalam desain pendekatan yang dilakukan jelas dengan analisis perilaku kehidupan yang dibantu dengn Kompedium Kampung Kota Jakarta, namun untuk menciptakan sebuah keruangan, penulis menerapkan metode desain dengan Experimental Material. Penggunaan material magnet dan paku sebagai implementasi perilaku mereka menjadi metaphor dan organik secara pemikiran. Desain yang dihasilkan berupa sebuah besi yang terhubung dengan indukan bangunan lama dengan implementasi sebuah simbiosis parasitisme. Bangunan menyediakan program dasar sebagai kebutuhan hidup bagi Generasi Alpha di kampung kota seperti living, office, communal space, public space, Workshop area, serta service. Ruang dapat berubah ubah sesuai kebutuhan individual yang tinggal. Proyek ini merupakan sebuah upaya bentuk protes sebuah kelayakan hidup bagi manusia yang mampu menyetarakan dirinya dengan Alpha yang ada saat ini. Menyelamatkan generasi Alpha dari perbedaan status sosial yang ada, kemajuan teknologi yang terlalu cepat membuat Alpha di kampung kota sangatlah tertinggal, oleh karena itu Hunian ini diciptakan sebagai sarana kebertahanan dari Alpha Kampung Kota.

\section{Saran}

Penelitian ini perlu disempurnakan untuk meningkatkan kualitas serta spatial dalam proyek ini dengan pendekatan masyarakat Alpha kampung kota, mengingat metode yang digunakan dalam penelitian bersifat eksperimen.

\section{REFERENSI}

Detik.com. (2020). Detik.com. Retrieved April 26, 2020, from Detik.com: https://news.detik.com/berita/d-4991485/kapan-sebenarnya-corona-pertama-kalimasuk-ri

ENSIKLOPEDI. (2017). Jakarta.go.id. Retrieved January 5, 2021, from https://www.jakarta.go.id/artikel/konten/4746/tanah-abang-kecamatan

Gumilang, I. (2018). Kompedium Kehidupan Kampung Kota Jakarta. Jakarta: Rujak Center For Urban Studies.

Hermawan. (2019). Tagar.id. Retrieved January 5, 2020, from https://www.tagar.id/sejarahpasar-tanah-abang

Mardatila, A. (2020). Sebelum COVID-19, Inilah Sejarah Virus Corona yang Menginfeksi Manusia. Retrieved Maret 18, 2020, from Merdeka.com: 
https://www.merdeka.com/jateng/sebelum-covid-19-inilah-sejarah-virus-corona-yangmenginfeksi-manusia-kln.html

McCrindle. (2020). Understanding Generation Alpha. Australia.

Putsanra, D. V. (2020). Arti PSBB yang Dibuat untuk Cegah Penyebaran Corona di Indonesia. Retrieved April 13, 2020, from Tirto.id: https://tirto.id/arti-psbb-yang-dibuat-untukcegah-penyebaran-corona-di-indonesia-eMXT

Sutanto, A. (2020). Peta Metode Desain. Jakarta: Jurusan Arsitektur dan Perencanaan Program Studi Arsitektur Universitas Tarumanagara.

tvOneNews. (2020). BERANI! Anak SMA Ini Kritik Nadiem Kalau Belajar untuk Pintar, Google Jauh Lebih Pintar! / tvOne. Retrieved Agustus 10, 2020, from tvOneNews:

https://www.youtube.com/watch?v=JS4eplyTI9Q 
